\title{
Effects of Genotype and Climatic Conditions on the Oil Content and Its Fatty Acids Composition of Carthamus tinctorius L. Seeds
}

\author{
Kamel Zemour ${ }^{1,2}{ }^{,}$Ahmed Adda ${ }^{2}$, Amina Labdelli ${ }^{2,3}{ }^{\circ}$, Abdelkader Dellal ${ }^{2}$, Muriel Cerny ${ }^{1}$ \\ and Othmane Merah 1,4,*iD \\ 1 Laboratoire de Chimie Agroindustrielle, Université de Toulouse, INRAE, 31030 Toulouse, France; \\ kamel.zemour@ensiacet.fr (K.Z.); muriel.cerny@ensiacet.fr (M.C.) \\ 2 Laboratory of Agro-Biotechnology and Nutrition in Semi-Arid Areas, University of Ibn Khaldoun, \\ Tiaret 14000, Algeria; adda2ahmed@yahoo.fr (A.A.); aminalabdelli@yahoo.fr (A.L.); \\ dellal05_aek@yahoo.fr (A.D.) \\ 3 Scientific and Technical Research Centre for Arid Areas (CRSTRA), Biskra 07000, Algeria \\ 4 Département Génie Biologique, Université Paul Sabatier, IUT A, 32000 Auch, France \\ * Correspondence: othmane.merah@ensiacet.fr; Tel.: +33-53-432-3523
}

check for

updates

Citation: Zemour, K.; Adda, A.; Labdelli, A.; Dellal, A.; Cerny, M.; Merah, O. Effects of Genotype and Climatic Conditions on the Oil Content and Its Fatty Acids Composition of Carthamus tinctorius L. Seeds. Agronomy 2021, 11, 2048. https://doi.org/10.3390/ agronomy11102048

Academic Editor: Tahmina Islam

Received: 12 September 2021

Accepted: 9 October 2021

Published: 12 October 2021

Publisher's Note: MDPI stays neutral with regard to jurisdictional claims in published maps and institutional affiliations.

Copyright: (c) 2021 by the authors. Licensee MDPI, Basel, Switzerland. This article is an open access article distributed under the terms and conditions of the Creative Commons Attribution (CC BY) license (https:// creativecommons.org/licenses/by/ $4.0 /)$.

\begin{abstract}
Safflower seeds provide an oil rich in mono and polyunsaturated fatty acids. Its adaptation to drought and high temperatures makes it an alternative for the development of oleaginous crops in semi-arid areas. This study examines the oil content and the chemical composition of seed oil from three safflower accessions (Gila, Halab, Touggourt) cultivated over three years $(2015,2016$ and 2017) in a semi-arid area in Tiaret (West of Algeria). Under these semi-arid conditions, characterized by low rainfall and high temperatures, seed oil content remained relatively high and was composed mainly of unsaturated fatty acids, with their ratio to saturated fatty acids reaching an average value of 9 . Seed oil content varies between $22.8 \%$ and $28.4 \%$ among the genotypes and throughout the three years. The extracted oil consists essentially of unsaturated fatty acids, linoleic and oleic acids, poly and monounsaturated, respectively. Their contents over the three years vary between $75 \%$ and $79.3 \%$ for linoleic acid and between $10.2 \%$ and $14.7 \%$ for oleic acid. The saturated fatty acids content of the oil reached a maximum value of $9 \%$. They consist mainly of palmitic acid, of which the average genotypic content varies between $6.6 \%$ and $7.15 \%$ depending on all grown years. The results obtained may assist in better understanding the response of cultivars under rainfed conditions and could be helpful for breeders with regards to introduction into selection programs.
\end{abstract}

Keywords: safflower; achene; semi-arid; oil; fatty acids

\section{Introduction}

Safflower (Carthamus tinctorius L.) is an asteracea, considered one of the oldest domesticated crops [1]. It originates from the Asian Fertile Crescent [2,3]. It presents an economic and medicinal interest for its seed oil and its flowers extract [4-6] and its place in the concept of biorefinery is undeniable [5,7]. Benefits of using safflower oil in food, pharmaceutical, and cosmetic applications have been demonstrated by several studies [8-11]. Its importance is mainly justified by its richness in unsaturated fatty acids, in particular oleic and linoleic acids [12]. Furthermore, linoleic acid represents a major unsaturated fatty acid in safflower oil, reaching a level of up to $88 \%$. However, other cultivars of this species show a high acid oleic content of up to $90.60 \%$ [13]. Oleic acid is characterized by a high single point of unsaturation which represents an attractive characteristic for industry due to the large range of potential chemical products. Oleic-rich safflower oil can be used in the production of varnishes, alcohols, paints, lubricants, cosmetics, detergents, and biobased plastics [14]. Likewise, safflower oil is distinguished by its richness in polyphenols, phytosterols, and tocopherols [12,15,16].

Safflower is known for its high adaptation to drought and high temperatures $[12,15,17,18]$. Therefore, its introduction in semi-arid regions would constitute an alternative in the 
development of oilseed crops. The effectiveness of this strategy necessarily requires studies to evaluate the effects of this environment on the profitability of the crop and the quality of the oil supplied. The results of work carried out under some of these conditions show that drought, associated with high temperatures, during the filling of the safflower grain reduces its oil content and modifies its composition [12,19-23]. The latter effect is reflected in a reduction of unsaturated fatty acids, particularly linoleic acid [12,24-26] and enrichment of the oil in polyphenols and phytosterols [12,15]. However, these studies require further investigation and must focus on effects of interactions of safflower genetic variability and climatic conditions on the oil biochemical traits. In the present study, these effects were estimated in Tiaret, located in the semi-arid zones of Algeria. For this purpose, three safflower accessions of different origins were grown for three years under rainfed conditions and the oil content of the seeds and its biochemical characteristics were estimated. An evaluation of the variations of these parameters according to the climatic conditions during the years of culture was the concern of this work.

\section{Materials and Methods}

\subsection{Plant Material and Experiments Conducting}

Three safflower accessions from different geographic origins were used for this study (Table 1). Experiments were carried out in clay-loam soil during three consecutive years $(2015,2016,2017)$ under rainfed conditions at the experimental farm of Ibn Khaldoun University of Tiaret $\left(35^{\circ} 20^{\prime} 01^{\prime \prime} \mathrm{N}, 1^{\circ} 18^{\prime} 48^{\prime \prime} \mathrm{E}\right)$ at $300 \mathrm{Km}$ in West of Algiers (Algeria). The design adopted is made up of three blocks. In each block the genotype is randomly arranged and occupies a microplot of $14 \mathrm{~m}^{2}$. The sowing was carried out in mid-April in rows spaced $0.3 \mathrm{~m}$ apart, in 11 rows with $4 \mathrm{~m}$ of each row length. In order to avoid edge effects, we used only the nine internal rows for measurements.

Table 1. Origins and main characteristics of the used safflower accessions.

\begin{tabular}{ccccc}
\hline Accession & Origin & Flower Colour & Leaf Aspect & $\begin{array}{c}\text { Precocity of } \\
\text { Maturity }\end{array}$ \\
\hline Touggourt & Algeria & Y,R & Without thorns & Late \\
Gila & France & W,Y,R & With thorns & Early \\
Halab & Syria & Y,R & With thorns & Early \\
\hline
\end{tabular}

Y: yellow; W: white; R: red.

The climatic data relating to the monthly average temperature in ${ }^{\circ} \mathrm{C}$ and the monthly rainfall in $\mathrm{mm}$ were recorded by meteorological station.

\subsection{Measurements Performed}

The harvest was carried out at the beginning of September at the physiological maturity of the seeds according to the $\mathrm{BBCH}$ scale [27]. Seeds were stored away from moisture and light until the start of measurements.

\subsubsection{Oil Extraction}

The oil was extracted using a Soxhlet apparatus [15]. This operation consists in using an organic solvent (cyclohexane) on a ground seed $(20 \mathrm{~g})$ for $6 \mathrm{~h}$ with a ratio of 1:10 (P:V). The solvent containing the oil is removed using a rotary evaporator at a temperature of $45^{\circ} \mathrm{C}$. The extracted oil is recovered in flasks and stored in the dark at a temperature of $4{ }^{\circ} \mathrm{C}$. The oil content is determined by:

$$
\text { Oil content }(\%)=\frac{\mathrm{W} 2 * 100}{\mathrm{~W} 1}
$$

where:

W1 is the initial weight of ground seed

W2 is the weight of extracted oil. 


\subsubsection{Determination of Fatty Acid Composition (GC Analysis)}

The method for analyzing the fatty acid composition is the same adopted by Roche et al. [28]. An aliquot of $20 \mathrm{mg}$ of oil is solubilized in $1 \mathrm{~mL}$ of Terbutyl methyl ether (TBME). After slight agitation, $100 \mu \mathrm{L}$ are taken and transferred to a suitable insert for transesterification by addition of $50 \mu \mathrm{L}$ of Trimethylsulfonium hydroxide (TMSH). This transesterification reaction takes place at the time of injection. The analyses were carried out with a gas chromatograph (Varian3900, Palo Alto, Milpitas, CA, USA). The temperature is programmed at $185^{\circ} \mathrm{C}$ for $40 \mathrm{~min}$, then raised to $250^{\circ} \mathrm{C}$ with a frequency of $15^{\circ} \mathrm{C} / \mathrm{min}$ and maintained there for $10.68 \mathrm{~min}$. The temperature of the injector and detector is set at $250{ }^{\circ} \mathrm{C}$. The pressure of the helium gas is $200 \mathrm{kPa}$.

\subsection{Statistical Analysis}

Statistical analyses were performed using Statistica software (version 8.0, USA). An analysis of variance and Fichier test were used to determine the effects of crop year, genotype, and the effect of their interaction on the content and fatty acids composition of the extracted oil. Means comparisons were performed using Newman-Keuls test at $p<0.05$ probability.

\section{Results}

\subsection{Climatic Parameters of the Experimentation Period}

The climatic parameters recorded during the three years of experimentation are mentioned in Table 2. The rainfall and temperature recorded during the three seasons were variable (Table 2). The first year (2015) was rainier than the other two. In addition, rainfall during the seed filling phase (June-August) was higher in the second year with a total of $38.1 \mathrm{~mm}$, while it was only $10.7 \mathrm{~mm}$ and $9.5 \mathrm{~mm}$ in 2016 and 2017, respectively. During this period of the year, the average temperature reached $24.12{ }^{\circ} \mathrm{C}(2015), 23.84{ }^{\circ} \mathrm{C}(2016)$, and $25.25{ }^{\circ} \mathrm{C}(2017)$.

Table 2. Climatic data for the three years $(2015,2016,2017)$ in Tiaret.

\begin{tabular}{ccccccc}
\hline & \multicolumn{2}{c}{$\mathbf{2 0 1 4 - 2 0 1 5}$} & \multicolumn{2}{c}{$\mathbf{2 0 1 5 - 2 0 1 6}$} & \multicolumn{2}{c}{$\mathbf{2 0 1 6 - 2 0 1 7}$} \\
\hline Month & $\begin{array}{c}\mathbf{T}^{\circ} \mathbf{C} \\
\mathbf{M e a n}\end{array}$ & $\begin{array}{c}\text { Rainfall } \\
\mathbf{( m m )}\end{array}$ & $\begin{array}{c}\mathbf{T}^{\circ} \mathbf{C} \\
\mathbf{M e a n}\end{array}$ & $\begin{array}{c}\text { Rainfall } \\
\mathbf{( m m )}\end{array}$ & $\begin{array}{c}\mathbf{T}^{\circ} \mathbf{C} \\
\mathbf{M e a n}\end{array}$ & $\begin{array}{c}\text { Rainfall } \\
(\mathbf{m m})\end{array}$ \\
\hline September & 22.88 & 75 & 21.39 & 18.7 & 21.37 & 4 \\
October & 18.07 & 14 & 17.14 & 83.9 & 18.52 & 8 \\
November & 12.22 & 50.1 & 10.29 & 26.2 & 9.63 & 53.8 \\
December & 6.27 & 94.8 & 8.48 & 0 & 6.55 & 30.1 \\
January & 6.2 & 50.7 & 8.52 & 39.6 & 3.98 & 201.8 \\
February & 4.91 & 121.2 & 8.64 & 62.7 & 9.03 & 9.8 \\
March & 8.7 & 7.7 & 8 & 88.3 & 10.05 & 4 \\
April & 15.3 & 0.0 & 12.8 & 24.6 & 13.0 & 6.8 \\
May & 19.2 & 12.7 & 16.4 & 26.7 & 19.8 & 26.0 \\
June & 21.1 & 7.4 & 21.7 & 6.5 & 25.2 & 0.4 \\
July & 27.0 & 0.0 & 26.7 & 0.2 & 26.8 & 1.0 \\
August & 27.0 & 12.0 & 25.6 & 0.0 & 27.7 & 4.8 \\
\hline Mean & 15.7 & - & 15.5 & - & 16 & - \\
\hline Total & - & 445.6 & - & 377.4 & - & 350.5 \\
\hline
\end{tabular}

\subsection{Oil Content}

The seeds oil content varies significantly depending on accessions (Table 3). The mean values were 28.4, 25.1, and 23.1\% for Halab, Gila and Touggourt genotypes in 2015, respectively. For 2016, an increase in the oil content was recorded by Gila and Touggourt, while, for Halab oil content decreased slightly (Table 4). In contrast, in 2017, a marked decrease in oil content was registered in all genotypes (Table 4). 
Table 3. Effect of accession, year and their interaction on the oil content and fatty acid composition of safflower seeds during 2015,2016 and 2017 cultivated in Tiaret.

\begin{tabular}{|c|c|c|c|c|c|c|c|c|c|c|c|c|}
\hline Factor & Df & $\begin{array}{c}\text { Oil } \\
\text { Content }\end{array}$ & C18:2n6 & C18:1n9 & C18:0 & C16:0 & C18:1n7 & C20:0 & C22:0 & UFA & SFA & UFA/SFA \\
\hline Accession & 2 & $5.87 *$ & $267^{* * *}$ & $497.5^{* * *}$ & $24.0^{* * *}$ & $17^{* * *}$ & $11.5^{* * *}$ & $41.44^{* * *}$ & $7.00^{* * *}$ & $29^{* * *}$ & $23^{* * *}$ & $25^{* * *}$ \\
\hline Year & 2 & $3.35 \mathrm{~ns}$ & $1293^{* * *}$ & $2691.9^{* * *}$ & $220.9^{* * *}$ & $443^{* * *}$ & $38.4^{* * *}$ & $127.44^{* * *}$ & $679.15^{* * *}$ & $164^{* * *}$ & $88^{* * * *}$ & $95^{* * *}$ \\
\hline
\end{tabular}

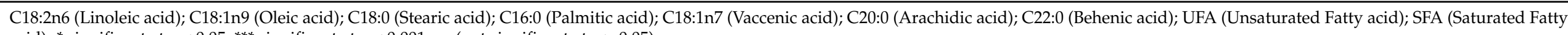
acid). ${ }^{*}$ significant at $p<0.05 ; * * *$ significant at $p<0.001$; ns (not significant at $p>0.05$ ).

Table 4. Oil content and its composition of saturated and polyunsaturated fatty acids in three safflower accessions during 2015,2016 and 2017 in Tiaret.

\begin{tabular}{|c|c|c|c|c|c|c|c|c|c|c|}
\hline & Year & & 2015 & & & 2016 & & & 2017 & \\
\hline & Accession & Halab & Gila & Touggourt & Halab & Gila & Touggourt & Halab & Gila & Touggourt \\
\hline & Oil Content (\%) & $28.4 \pm 0.17$ a & $25.1 \pm 3.02 \mathrm{a}$ & $23.1 \pm 1.81$ a & $27.8 \pm 0.90 \mathrm{a}$ & $27.5 \pm 0.26 \mathrm{a}$ & $26.4 \pm 1.13 \mathrm{a}$ & $26.9 \pm 0.09 b$ & $23.9 \pm 0.12 \mathrm{a}$ & $22.8 \pm 0.60 \mathrm{a}$ \\
\hline \multirow{4}{*}{$\begin{array}{l}\text { Saturated Fatty } \\
\text { Acids (\%) }\end{array}$} & C18:0 & $2.2 \pm 0.01 \mathrm{c}$ & $2.1 \pm 0.02 \mathrm{~b}$ & $1.9 \pm 0.00 \mathrm{a}$ & $1.9 \pm 0.02 \mathrm{a}$ & $1.8 \pm 0.01 \mathrm{~b}$ & $1.9 \pm 0.01 \mathrm{a}$ & $1.9 \pm 0.00 \mathrm{a}$ & $1.9 \pm 0.00 \mathrm{a}$ & $2.1 \pm 0.00 \mathrm{~b}$ \\
\hline & C20:0 & $0.33 \pm 0.01 \mathrm{a}$ & $0.32 \pm 0.0 \mathrm{a}$ & $0.28 \pm 0.0 \mathrm{~b}$ & $0.33 \pm 0.0 \mathrm{~b}$ & $0.32 \pm 0.0 \mathrm{a}$ & $0.31 \pm 0.0 \mathrm{a}$ & $0.36 \pm 0.0 \mathrm{a}$ & $0.33 \pm 0.0 \mathrm{~b}$ & $0.36 \pm 0.0 \mathrm{a}$ \\
\hline & $\mathrm{C} 22: 0$ & $0.22 \pm 0.0 \mathrm{a}$ & $0.21 \pm 0.0 \mathrm{a}$ & $0.23 \pm 0.0 \mathrm{a}$ & $0.24 \pm 0.0 \mathrm{a}$ & $0.25 \pm 0.0 \mathrm{a}$ & $0.23 \pm 0.0 \mathrm{a}$ & $0.44 \pm 0.0 \mathrm{~b}$ & $0.38 \pm 0.0 \mathrm{a}$ & $0.41 \pm 0.0 \mathrm{a}$ \\
\hline & Total SFA & $9.58 \pm 0.02 \mathrm{a}$ & $9.63 \pm 0.01 b$ & $9.56 \pm 0.0 \mathrm{a}$ & $9.49 \pm 0.03 \mathrm{a}$ & $9.35 \pm 0.02 \mathrm{~b}$ & $9.43 \pm 0.01 \mathrm{a}$ & $9.4 \pm 0.03 \mathrm{~b}$ & $9.2 \pm 0.03 \mathrm{a}$ & $9.5 \pm 0.01 \mathrm{c}$ \\
\hline Monounsaturated & C18:1n9 & $12.5 \pm 0.04 \mathrm{c}$ & $12.0 \pm 0.02 \mathrm{~b}$ & $10.2 \pm 0.02 \mathrm{a}$ & $12.9 \pm 0.09 c$ & $12.3 \pm 0.03 \mathrm{~b}$ & $10.7 \pm 0.07 \mathrm{a}$ & $12.6 \pm 0.01 \mathrm{a}$ & $14.3 \pm 0.00 \mathrm{~b}$ & $14.7 \pm 0.01 \mathrm{c}$ \\
\hline Fatty Acids (\%) & C18:1n7 & $0.78 \pm 0.0 \mathrm{a}$ & $0.8 \pm 0.0 \mathrm{~b}$ & $0.83 \pm 0.0 \mathrm{c}$ & $0.84 \pm 0.0 \mathrm{c}$ & $0.81 \pm 0.0 \mathrm{~b}$ & $0.77 \pm 0.0 \mathrm{a}$ & $0.79 \pm 0.0 \mathrm{c}$ & $0.77 \pm 0.0 \mathrm{~b}$ & $0.76 \pm 0.0 \mathrm{a}$ \\
\hline \multirow{3}{*}{$\begin{array}{l}\text { Polyounsaturated } \\
\text { Fatty Acids (\%) }\end{array}$} & C18: 2n6 & $77.1 \pm 0.06 \mathrm{a}$ & $77.5 \pm 0.02 \mathrm{~b}$ & $79.3 \pm 0.01 \mathrm{c}$ & $76.7 \pm 0.1 \mathrm{a}$ & $77.5 \pm 0.03 \mathrm{~b}$ & $79.1 \pm 0.09 c$ & $77.2 \pm 0.03 c$ & $75.7 \pm 0.00 \mathrm{~b}$ & $75.0 \pm 0.02 \mathrm{a}$ \\
\hline & Total UFA & $90.38 \pm 0.03 a$ & $90.29 \pm 0.01 b$ & $90.36 \pm 0.01 \mathrm{a}$ & $90.42 \pm 0.03 \mathrm{~b}$ & $90.58 \pm 0.02 \mathrm{a}$ & $90.51 \pm 0.01 \mathrm{a}$ & $90.59 \pm 0.03 b$ & $90.81 \pm 0.00 \mathrm{c}$ & $90.47 \pm 0.01 \mathrm{a}$ \\
\hline & UFA/SFA & $9.4 \pm 0.02 \mathrm{a}$ & $9.4 \pm 0.01 \mathrm{~b}$ & $9.4 \pm 0.0 \mathrm{a}$ & $9.5 \pm 0.03 \mathrm{a}$ & $9.7 \pm 0.02 b$ & $9.6 \pm 0.01 \mathrm{a}$ & $9.6 \pm 0.03 \mathrm{~b}$ & $9.8 \pm 0.04 \mathrm{a}$ & $9.5 \pm 0.01 \mathrm{c}$ \\
\hline
\end{tabular}

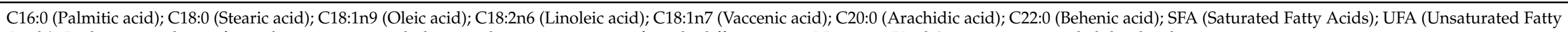

Acids). In the same column, for each year, means with the same letter were not significantly different using Newman-Keuls' test at $p>0.05$ probability level. 


\subsection{Fatty Acids Composition Determined with GC Analysis}

During the three years of experimentation, the extracted oil from the tested genotypes consists mainly of unsaturated fatty acids with an average content of $90.5 \%$. In the same situations, saturated fatty acids have a low rate of $9 \%$ (Table 4 ).

The fraction of unsaturated fatty acids consists of linoleic acid, oleic acid, and vaccenic acid. For the three genotypes and during the three years of experimentation, polyunsaturated linoleic acid represents the main constituent of this category of fatty acid (Table 4). Its contents varied between 75 and 79.3\% recorded by Touggourt genotype in 2017 and 2015, respectively. It can be seen that the highest levels of this acid were recorded in 2015 (Table 4).

The oleic acid contents ranged between 10.2 and 14.7\% registered by Touggourt genotype in 2015 and 2017, respectively. Thus, the levels of this fatty acid increased over the three years to reach their maximum during 2017 (Table 4).

The saturated fatty acid is represented mainly by palmitic and stearic acid with respective average contents of $6.89 \%$ and $1.97 \%$. Any variation in the levels of these fatty acids was noted among the genotypes and according to the year of experimentation (Table 3). Generally, the values of the palmitic acid and stearic acid were moderately lower in the latest year (2017) compared to 2015 and 2016 (Table 4). Thus, the results showed that the arachidic and behenic acid have mean values of 0.33 and $0.29 \%$, respectively, over the three years of experimentation. It has been demonstrated that the total of saturated fatty acids revealed a low value in 2017 compared to 2015 and 2016 (Table 4).

\section{Discussion}

The importance given to safflower is mainly related to the oil produced from its seeds [5]. The oil content reached the rate of $28 \%$ (Table 4 ) and ranged from $22.8 \%$ registered for Touggourt in 2017 and $28.4 \%$ showed by Halab in 2015. The oil content variation has been shown to vary largely according to the environmental parameters $[29,30]$. In these studies, obtained values ranged between $15 \%$ and $40 \%$. Consequently, our results showed that the safflower seeds produce an appreciable oil content under semi-arid area conditions.

The nature of cultivars appears also to be determining for the oil content of this species [31-35]. Some morphological traits of the tested genotypes present as indicators of seed oil richness. In fact, our study has demonstrated that the genotypes with spiny leaves (Halab, Gila) form seed richer in oil than Touggourt, a thornless genotype (Table 4). Similar results were reported by Kizil et al. [36] and Ashrafi and Razmjoo [25].

In our study, the lowest value of oil content had been recorded in 2017 (Table 4). This year was the warmest and the least rainy of the three years (Table 2). Indeed, during 2017, the beginning of the seed filling phase has coincided with low preciptation $(0.4 \mathrm{~mm})$ and high temperature in June (Table 2). Among the environmental parameters, drought, associated with high temperatures, reduced this content significantly at the end of the development cycle [25,37-41]. They affect photosynthetic activity and the availability of assimilates indispensable for reserves constitution during grain filling [42,43]. Also, the decrease in seed oil content is caused by alteration of the metabolic pathways essential to synthesis and accumulation of oil and by effectation of the enzymatic activities responsible for this process [44,45]. Seghal et al. [46] have indicated that under drought conditions the decrease in oil content is due to reduction in concentration of digestible carbohydrates and unloading of sugars from stem to developing seeds.

Safflower is an oleaginous species of significant interest due to its fatty acid variability content in the seed oil $[47,48]$. Our study indicates that extracted oil is very rich in unsaturated fatty acids, where their rate has reached a maximum value of $90.59 \%$ (Halab) and 90.81\% (Gila). These results are confirmed by those obtained by Benmoumen et al. [16], Ergönül and Özbek [49], and Taha and Matthäus [50]. Among these compounds, linoleic acid (polyunsaturated fatty acid) has the most important fraction and reaches a level of $70 \%$. In contrast, a low presence of saturated fatty acids, mainly palmitic acid, has been reported $[12,25]$. These results divulge the high ratio of unsaturated fatty acids and saturated 
fatty acids in safflower oil which, according to Wood et al. [51], represents a determining criterion for evaluation of the nutritional quality of food oils.

Plant quality trait improvement has become a global necessity due to global overpopulation [52]. The study of plant metabolomics is important to improve crop yields and quality, and ensure nutritional and health factors that provide the opportunity to produce functional food [53].

The fatty acids composition is dependent on the nature of the cultivars and the prevailing climatic conditions during their crop cycle (Table 3). Indeed, this dependence has been previously proven by Uitterhaegen et al. [54], Roche et al. [12] and Nguyen et al. [55]. In 2017, the accessions recorded low values of linoleic acid. However, in the same year, oleic acid values were higher than those registered in 2015 and 2016 (Table 4). According to Flagella et al. [56], Kizil et al. [36] and Khoufi et al. [57], a drought accompanied by a rise in temperature leads to an increase in oleic acid levels and a decrease in linoleic acid. These abiotic stresses inhibit the function of the delta 12 desaturase enzyme which is responsible for conversion of oleic acid into linoleic acid [58]. In addition, an increase in temperature leads to a decrease in the activity of the microsomal oleate desaturase FAD2 in safflower and sunflower [59-61]. Allakhverdiev et al. [62] have realized that the augmentation of the polyunsaturated fatty acid in membrane lipids is able to conserve the plant's photosynthetic system. Other research has confirmed that abiotic stress such as saline stress leads to an increased proportion of unsaturated fatty acids [63]. In the biotechnology field, the study of the effect of these factors on seed oil quality gives an opportunity to develop tolerant safflowers genotypes having desirable fatty acid traits.

In this study, it has been demonstrated that for the saturated fatty acids palmitic and stearic acid, their rate has been decreased under conditions of drought and high temperature. Similar results have been confirmed by Ashrafi and Razmjoo [25]. These authors have found that drought stress decreased saturated fatty acid content which consequently reduced the oil content in the seeds of safflower. However, Gao et al. [64] have noticed that the fatty acid composition differed when soybean plant was subjected to drought stress, along with a decrease in palmitic and an increase of stearic acid. Generally, Lacombe et al. [65] have indicated that the composition of saturated fatty acids changed into unsaturated fatty acids under drought stress.

Drought is one of the most severe and unpredictable abiotic stresses, occurring at any growth stage and affecting crop yields [66]. It presents a substantial challenge to the sustainability of agriculture [67]. For this reason, studying the genetic diversity of safflower could provide valuable information on germplasm maintenance and utilization for breeders to improve breeding programs for semi-arid areas to ensure sustainable crop production $[68,69]$.

\section{Conclusions}

This study showed that safflower achenes grown in a semi-arid area of Algeria provided an oil content rich in unsaturated fatty acids. Among these components, linoleic acid and oleic acid are the most present. These compounds may play an important role in pharmaceutical and nutritional utilisation. The environmental conditions of this region, i.e., low rainfall and high temperature, govern an interspecific variability in the expression of these parameters. They modified the quality of the examined oil by increasing the level of oleic acid and decreasing the level of linoleic acid. However, they decreased the seed oil content of all studied genotypes.

The adaptation of safflower in such areas requires a large real investment in order to take advantage of the economic and biochemical components provided by the oil extracted from its seeds. Also, both halab and Gila accessions have the highest value of polyunsaturated fatty acids and oil content. Consequently, the introduction of these two genotypes in a breeding program could obtain a novel genotype having desirable traits, notably in limiting climatic conditions. 
Author Contributions: Conceptualization, O.M., A.A.; methodology, K.Z., M.C. and A.L.; formal analysis, K.Z., M.C., A.L. and O.M., writing-original draft preparation, K.Z., A.L., A.A., A.D. and M.C.; writing-review and editing, O.M. and A.A.; supervision, O.M.; project administration, O.M., A.D. and A.A. All authors have read and agreed to the published version of the manuscript.

Funding: This research received no external funding.

Acknowledgments: Kamel Zemour was partially supported by the Hubert Curien-Tassili program 16MDU953.

Conflicts of Interest: The authors declare no conflict of interest. The funders had no role in the design of the study; in the collection, analyses, or interpretation of data; in the writing of the manuscript or in the decision to publish the results.

\section{References}

1. Hamdan, Y.A.S.; García-Moreno, M.J.; Redondo-Nevado, J.; Velasco, L.; Pérez-Vich, B. Development and characterization of genomic microsatellite markers in safflower (Carthamus tinctorius L.). Plant Breed. 2011, 130, 237241. [CrossRef]

2. Talebi, R.; Nosrati, S.; Etminan, A.; Naji, A.M. Genetic diversity and population structure analysis of landrace and improved safflower (Cartamus tinctorious L.) germplasm using arbitrary functional gene-based molecular markers. Biotechnol. Biotechnol. Equip. 2018, 32, 1183-1194. [CrossRef]

3. Ren, C.X.; Wu, Y.Y.; Tang, X.H.; Hu, J.; Chen, J.; Wu, Q.H.; Pei, J. Safflower's origin and changes of producing areas. China J. Chin. Mater. Med. 2017, 42, 2219-2222. [CrossRef]

4. Li, D.; Mündel, H.H. Safflower (Carthamus tinctorius L.) Promoting the Conservation and Use of Underutilized and Neglected Crops; Institute of Plant Genetics and Crop Plant Research, Gatersleben/International Plant Genetic Resources Institute: Rome, Italy, 1996; 83p.

5. Zemour, K.; Adda, A.; Zebib, B.; Merah, O. Le carthame (Carthamus tinctorius L.): Une oléagineuse qui n'a pas dit son dernier mot en Algérie. Agrobiologia 2020, 10, 2211-2219.

6. Du, C.; Hou, J.; Wang, C.; Zhang, M.; Zheng, Y.; Yang, G.; Hu, Y. Effects of safflower yellow on cholesterol levels in serum and brain tissue of APP/PS 1 mice. Metab. Brain Dis. 2021, 36, 557-569. [CrossRef] [PubMed]

7. Hashemi, S.S.; Mirmohamadsadeghi, S.; Karimi, K. Biorefinery development based on whole safflower plant. Renew. Energy 2020, 152, 399-408. [CrossRef]

8. Asgarpanah, J.; Kazemivash, N. Phytochemistry, pharmacology and medicinal properties of Carthamus tinctorius L. Chin. J. Int. Med. 2013, 19, 153-159. [CrossRef]

9. Khalid, N.; Khan, R.S.; Hussain, M.I.; Farooq, M.; Ahmad, A.; Ahmed, I. Comprehensive characterisation of safflower oil for its potential applications as a bioactive food ingredient-A review. Trends Food Sci. Technol. 2017, 66, 176-186. [CrossRef]

10. Labdelli, A.; Zemour, K.; Simon, V.; Cerny, M.; Adda, A.; Merah, O. Pistacia atlantica Desf., a Source of Healthy Vegetable Oil. Appl. Sci. 2019, 12, 2552. [CrossRef]

11. Sayed Ahmad, B.; Talou, T.; Saad, Z.; Hijazi, A.; Cerny, M.; Kanaan, H.; Chokr, A.; Merah, O. Fennel seed oil and by-products characterization and their potential applications. Ind. Crops Prod. 2018, 111, 92-98. [CrossRef]

12. Roche, J.; Mouloungui, Z.; Cerny, M.; Merah, O. Effect of sowing dates on fatty acids and phytostérols patterns of Carthamus tinctorius L. Appl. Sci. 2019, 9, 2839. [CrossRef]

13. Fernández-Martínez, J.; Rio, M.D.; Haro, A.D. Survey of safflower (Carthamus tinctorius L.) germplasm for variants in fatty acid composition and other seed characters. Euphytica 1993, 69, 115-122. [CrossRef]

14. Velasco, L.; Fernández-Martínez, J. Breeding for oil quality in Safflower. In Proceedings of the 5th International Safflower Conference, Williston, ND, USA, 23-27 July 2001; North Dakota State University: Fargo, ND, USA, 2001; pp. $133-137$.

15. Zemour, K.; Labdelli, A.; Adda, A.; Dellal, A.; Talou, T.; Merah, O. Phenol content and antioxidant and antiaging activity of safflower seed oil (Carthamus tinctorius L.). Cosmetics 2019, 6, 55. [CrossRef]

16. Ben Moumen, A.; Mansouri, F.; Richard, G.; Abid, M.; Fauconnier, M.L.; Sindic, M.; ElAmrani, A.; Caid, H.S. Biochemical characterisation of the seed oils of four safflower (Carthamus tinctorius) varieties grown in north-eastern of Morocco. Int. J. Food Sci. Technol. 2014, 50, 804-810. [CrossRef]

17. Lovelli, S.; Perniola, M.; Ferrara, A.; Di Tommaso, T. Yield response factor to water (Ky) and water use efficiency of Carthamus tinctorius L. and Solanum melongena L. Agric. Water Manag. 2007, 92, 73-80. [CrossRef]

18. Hussain, M.I.; Lyra, D.A.; Farooq, M.; Nikoloudakis, N.; Khalid, N. Salt and drought stresses in safflower: A review. Agron. Sustain. Dev. 2015, 36, 1-31. [CrossRef]

19. Dwivedi, S.L.; Nigam, S.N.; Jambunathan, R.; Sahrawate, K.L.; Nagabhushanam, G.V.S.; Raghunath, K. Effects of genotypes and environments on oil content and oil quality parameters and their correlations in peanut (Arachishypogaea L.). Peanut Sci. 1993, 20, 84-89. [CrossRef]

20. Izquierdo, N.G.; Aguirrezábal, L.A.N.; Andrade, F.H.; Cantarero, M.G. Modeling the response of fatty acid composition to temperature in a traditional sunflower hybrid. J. Agron. 2006, 98, 451-461. [CrossRef]

21. Roche, J.; Alignan, M.; Bouniols, A.; Cerny, M.; Mouloungui, Z.; Merah, O. Sterol concentration and distribution in sunflower seeds (Helianthus annuus L.) during seed development. Food Chem. 2010, 119, 1451-1456. [CrossRef] 
22. Whaley, R.; Eskandari, M. Genotypic main effect and genotype-by-environment interaction effect on seed protein concentration and yield in food-grade soybeans (Glycine max (L.) Merrill). Euphytica 2019, 215, 1-17. [CrossRef]

23. Navas-López, J.F.; Cano, J.; de la Rosa, R.; Velasco, L.; León, L. Genotype by environment interaction for oil quality components in olive tree. Eur. J. Agric. 2020, 119, 126115. [CrossRef]

24. Samanci, B.; Özkaynak, Q. Effect of planting date on seed yield, oil content and fatty acid composition of safflower (Carthamus tinctorius L.) cultivars grown in the mediterranean region of Turkey. J. Agric. Crop Sci. 2003, 189, 359-360. [CrossRef]

25. Ashrafi, E.; Razmjoo, K. Effect of irrigation regimes on oil content and composition of safflower (Carthamus tinctorius L.) cultivars. J. Am. Oil Chem. Soc. 2010, 87, 499-506. [CrossRef]

26. Zraibi, L.; Kajeiou, M.; Caid, H.S.; Nabloussi, A. Safflower evaluation under contrasted environment conditions and selection of promising genotypes. J. Agric. Sci. Technol. 2014, 4, 299-311. [CrossRef]

27. Flemmer, A.C.; Franchini, M.C.; Lindström, L.I. Description of safflower (Carthamus tinctorius) phenological growth stages according to the extended BBCH scale. Ann. Appl. Biol. 2014, 2, 331-339. [CrossRef]

28. Roche, J.; Mouloungui, Z.; Cerny, M.; Merah, O. Fatty acid and phytosterol accumulation during seed development in three oilseed species. Int. J. Food. Sci. Technol. 2016, 51, 1820-1826. [CrossRef]

29. Sung, J.; Jeong, Y.; Kim, S.; Luitel, B.P.; Ko, H.; Hur, O.; Yoon, M.; Rhee, J.; Baek, H.; Ryu, K. Fatty acid composition and antioxidant activity in safflower germplasm collected from South Asia and Africa. J. Korean Soc. Int. Agric. 2016, 28, 342-351. [CrossRef]

30. Dordas, C.A.; Sioulas, C. Safflower yield, chlorophyll content, photosynthesis, and water use efficiency response to nitrogen fertilization under rainfed conditions. Ind. Crops Prod. 2008, 27, 75-85. [CrossRef]

31. Roche, J.; Alignan, M.; Bouniols, A.; Jane Roche, J.; Alignan, M.; Bouniols, A.; Cerny, M.; Mouloungui, Z.; Vear, F.; Merah, O. Sterol content in sunflower seeds (Helianthus annuus L.) as affected by genotypes and environmental conditions. Food Chem. 2010, 121, 990-995. [CrossRef]

32. Anastasi, U.; Santonoceto, C.; Giuffrè, A.M.; Sortino, O.; Gresta, F.; Abbate, V. Yield performance and grain lipid composition of standard and oleic sunflower as affected by water supply. Filed Crops Res. 2010, 119, 145-153. [CrossRef]

33. Golkar, P.; Arzani, A.; Rezaei, A.M. Genetic analysis of oil content and fatty acid composition in safflower (Carthamus tinctorius L.). J. Am. Oil. Chem. Soc. 2011, 88, 975-982. [CrossRef]

34. Sung, J.S.; Ko, H.C.; Hur, O.S.; Kim, S.G.; Lee, J.R.; Luitel, B.P.; Lee, Y.H.; Jang, Y.S.; Gwag, J.G.; Baek, H.J.; et al. Morphological and oil compositions in safflower (Carthamus tinctorius L.) germplasm of different geographical groups. J. Korean Soc. Int. Agric. 2016, 28, 84-91. [CrossRef]

35. El-Lattief, E.A. Evaluation of 25 safflower genotypes for seed and oil yields under arid environment in upper Egypt. Asia J. Crop Sci. 2012, 4, 72-79. [CrossRef]

36. Kizil, S.; Çakmak, O.; Kirici, S.; İnan, M. A comprehensive study on safflower (Carthamus tinctorius L.) in semi-arid conditions. Biotechnol. Biotechnol. Equip. 2008, 22, 947-953. [CrossRef]

37. Istanbulluoglu, A.; Gocmen, E.; Gezer, E.; Pasa, C.; Konukcu, F. Effects of water stress at different development stages on yield and water productivity of winter and summer safflower (Carthamus tinctorius L.). Agric. Water Manag. 2009, 96, 1429-1434. [CrossRef]

38. Fernández-Cuesta, Á.; Velasco, L.; Ruiz-Méndez, M.V. Novel safflower oil with high $\gamma$-tocopherol content has a high oxidative stability. Eur. J. Lipid Sci. Technol. 2014, 116, 832-836. [CrossRef]

39. Pritchard, F.M.; Eagles, H.A.; Norton, R.M.; Salisbury, S.A.; Nicolas, M. Environmental effects on seed composition of Victorian canola. Aust. J. Exp. Agric. 2000, 40, 679-685. [CrossRef]

40. Quadir, G.; Ahmad, S.; Hassan, F.; Cheema, M.A. Oil and fatty acid accumulation in sunflower as influenced by temperature variation. Pak. J. Bot. 2006, 38, 1137-1147.

41. Oraki, H.; Alahdadi, I.; Khajani, F.P. Influence of water deficit and genotype on protein, oil contents and some physical characteristics of sunflower seeds. Afr. J. Agric. Res. 2011, 6, 1246-1250. [CrossRef]

42. Zahedi, H.; Noormohammadi, G.; Rad, A.H.S.; Habibi, D.; Boojar, M.M.A. The effects of zeolite and foliar application of Selenium on growth, yield and yield components of three canola cultivars under drought stress. World Appl. Sci. J. 2009, 7, $255-262$. [CrossRef]

43. Kafi, M.; Rostami, M. Yield characteristics and oil content of three safflower (Carthamus tinctorius L.) cultivars under drought in reproductive stage and irrigation with saline water. Iran Agron. Res. 2008, 5, 121-131.

44. Koocheki, A.; Ebrahimian, E.; Seyyedi, S.M. How irrigation rounds and mother corm size control saffron yield, quality, daughter corms behavior and phosphorus uptake. Sci. Hortic. 2016, 213, 132-143. [CrossRef]

45. Fahad, S.; Bajwa, A.A.; Nazir, U.; Anjum, S.A.; Farooq, A.; Zohaib, A.; Sadia, S.; Nasim, W.; Adkins, S.; Saud, S.; et al. Crop production under drought and heat stress: Plant responses and management options. Front. Plant Sci. 2017, 8, 1-16. [CrossRef]

46. Sehgal, A.; Kumari, S.; Siddique, K.H.M.; Kumar, R.; Bhogireddy, S.; Varshney, R.K.; Hanumantharao, B.; Nair, M.R.; Vara Prasad, P.V.; Nayyar, H. Drought or/and Heat-stress Effects on Seed Filling in Food Crops: Impacts on Functional Biochemistry, Seed Yields and Nutritional Quality. Front. Plant Sci. 2018, 9, 1705. [CrossRef]

47. La Bella, S.; Tuttolomondo, T.; Lazzeri, L.; Matteo, R.; Leto, C.; Licata, M. An Agronomic Evaluation of New Safflower (Carthamus tinctorius L.) Germplasm for Seed and Oil Yields under Mediterranean Climate Conditions. Agronomy 2019, 9, 468. [CrossRef] 
48. Yassein, A.A.M.; Khalaf, A.E.A.; Mohdaly, A.A.A.; Roby, M.H.H. Selections of donors depending on agronomic traits, seed yield components, and fatty acid profile for genetic improvement of Carthamus using stepwise multiple regression. OCL 2020, 27, 66. [CrossRef]

49. Ergönül, P.G.; Özbek, Z.A. Identification of bioactive compounds and total phenol contents of cold pressed oils from safflower and camelina seeds. J. Food Meas. Charact. 2018, 12, 2313-2323. [CrossRef]

50. Taha, E.; Matthäus, B. Study of safflower varieties cultivated under southern Egypt conditions for seeds and flowers. J. Biol. Sci. 2018, 18, 74-83. [CrossRef]

51. Wood, J.D.; Richardson, G.R.; Fisher, A.V. Effects of fatty acids on meat quality: A review. Meat Sci. 2003, 66, 21-32. [CrossRef]

52. Pott, D.M.; Durán-Soria, S.; Osorio, S.; Vallarino, J.G. Combining metabolomic and transcriptomic approaches to assess and improve crop quality traits. CABI Agric. Biosci. 2021, 2, 1. [CrossRef]

53. Mani, V.; Lee, S.K.; Yeo, Y.; Hahn, B.S. A Metabolic Perspective and Opportunities in Pharmacologically Important Safflower. Metabolites 2020, 10, 253. [CrossRef] [PubMed]

54. Uitterhaegen, E.; Nguyen, Q.H.; Sampaio, K.A.; Stevens, C.V.; Merah, O.; Talou, T.; Evon, P. Extraction of vegetable oil from coriander seeds originating from France using a twin-screw extruder: Feasibility study and potential uses of the obtained press cakes. J. Am. Oil Chem. Soc. 2015, 92, 1219-1233. [CrossRef]

55. Nguyen, Q.H.; Talou, T.; Evon, P.; Cerny, M.; Merah, O. Fatty acid composition and oil content during coriander fruit development. Food Chem. 2020, 326, 127034. [CrossRef] [PubMed]

56. Flagella, Z.; Rotunno, T.; Tarantino Di Caterina, R.; De Caro, A. Changes in seed yield and oilfatty acid composition of high oleic sunflower (Helianthus annuus L.) hybrids in relation to the sowing date and the water regime. Eur. J. Agron. 2002, 17, 221-230. [CrossRef]

57. Khoufi, S.; Khamassi, K.; Da Silva, J.A.T.; Rezgui, S.; Ben Jeddi, F. Watering regime affects oil content and fatty acid composition of six sunflower lines. J. New Sci. 2014, 7, 1-9.

58. Garcés, R.; Mancha, M. In vitro oleatedesaturase in developing sunflower seeds. Phytochemistry 1991, 30, 2127-2130. [CrossRef]

59. Esteban, A.B.; Sicardo, M.D.; Mancha, M.; Martinez-Rivas, J.M. Growth temperature control of the linoleic acid content in safflower (Carthamus tinctorius) seed oil. J. Agric. Food Chem. 2004, 52, 332-336. [CrossRef] [PubMed]

60. Rolletschek, H.; Borisjuk, L.; Sanchez-Garcia, A.; Gotor, C.; Romero, L.C.; Martinez-Rivas, J.M.; Mancha, M. Temperature dependent endogenous oxygen concentration regulates microsomal oleatedesaturase in developing sunflower seeds. J. Exp. Bot. 2007, 58, 3171-3181. [CrossRef] [PubMed]

61. Martínez-Rivas, J.M.; Sanchez-García, A.; Sicardo, M.D.; García-Díaz, M.T.; Mancha, M. Oxygen-independent temperature regulation of the microsomal oleatedesaturase (FAD2) activity in developing sunflower (Helianthus annuus) seeds. Physiol. Plant. 2003, 117, 179-185. [CrossRef]

62. Allakhverdiev, S.I.; Kinoshita, M.; Inaba, M.; Suzuki, I.; Murata, N. Unsaturated fatty acids in membrane lipids protect the photosynthetic machinery against salt-induced damage in Synechococcus. Plant Physiol. 2001, 125, 1842-1853. [CrossRef]

63. Yang, W.; Wang, F.; Liu, L.N.; Sui, N. Responses of Membranes and the Photosynthetic Apparatus to Salt Stress in Cyanobacteria. Front. Plant Sci. 2020, 11, 713. [CrossRef]

64. Gao, J.; Hao, X.; Thelen, K.D.; Robertson, G.P. Agronomic management system and precipitation effects on soybean oil and fatty acid profiles. Crop Sci. 2009, 49, 1049-1057. [CrossRef]

65. Lacombe, S.; Souyris, I.; Bervillé, A.J. An insertion of oleatedesaturase homologous sequence silences via siRNA the functional gene leading to high oleic acid content in sunflower seed oil. Mol. Genet. Genom. 2009, 281, 43-54. [CrossRef] [PubMed]

66. Joshi, S.; Thoday-Kennedy, E.; Daetwyler, H.D.; Hayden, M.; Spangenberg, G.; Kant, S. High-throughput phenotyping to dissect genotypic differences in safflower for drought tolerance. PLOS ONE 2021, 16, e0254908. [CrossRef] [PubMed]

67. Kumari, V.V.; Roy, A.; Vijayan, R.; Banerjee, P.; Verma, V.C.; Nalia, A.; Pramanik, M.; Mukherjee, B.; Ghosh, A.; Reja, M.H.; et al. Drought and heat stress in cool-season food legumes in sub-tropical regions: Consequences, adaptation, and mitigation strategies. Plants 2021, 10, 1038. [CrossRef] [PubMed]

68. Gholami, M.; Sabaghnia, N.; Nouraein, M.; Shekari, F.; Janmohammadi, M. Cluster analysis of some safflower genotypes using a number of agronomic characteristics. J. Crop Breed. 2018, 10, 159-166. [CrossRef]

69. Mousavi Ojaq, S.M.; Mozafari, H.; Jabbari, H.; Sani, B. Evaluation of yield of safflower (Carthamus tinctorius L.) genotypes under semi-arid conditions. Plant Genet. Resour. Charact. Util. 2020, 18, 270-277. [CrossRef] 